\title{
Synthesis, Characterization and Cytotoxic Activity of some New 1,2,3-Triazole, Oxadiazole and Aza- $\beta$-lactam Derivatives
}

\author{
KANY A. ABDUL QADER ${ }^{1 *}$, AHMED W. NASER ${ }^{1}$, MUTHANNA S. FARHAN² \\ and SABAH J. SALIH ${ }^{2}$
}

\begin{abstract}
${ }^{1}$ Department of Chemistry, College of Science, University of Baghdad, Baghdad, Iraq. 2Department of Pharmaceutical Chemistry, College of Pharmacy, University of Baghdad, Baghdad, Iraq. ${ }^{*}$ Corresponding author E-mail: kaneeazad@yahoo.com
\end{abstract}

http://dx.doi.org/10.13005/ojc/340516

(Received: April 08, 2018; Accepted: August 10, 2018)

\begin{abstract}
A series of 1,2,3-triazole, oxadiazole and aza- $\beta$-lactam derivatives were synthesized through consecutive reaction began from o-( $\mathrm{N}$-propargyl) sulfonamido benzoic acid (1a). The reaction of (1a) with absolute ethanol in the presence of concentrated $\mathrm{H}_{2} \mathrm{SO}_{4}$ resulted in the formation of ester derivative (2a). The product of the previous reaction was reacted with $80 \%$ hydrazine hydrate to prepare benzohydrazide derivative (3a). 1,3,4-oxadiazole compound (4a) was obtained by condensation of compound (3a) with $\mathrm{CS}_{2}$ in presence $\mathrm{KOH}$. Compound (3a) react with Phenyl isocyanates to give Carboxamide derivative (5a), that Condensation either with 2,4-dimethoxybenzaldhyde and p-hydroxybenzaldehyde to prepare the Schiff bases (6a-b). The cycloaddotion of Schiff-bases (6a-b) with phenyl isocyanate gave aza- $\beta$-lactams (7a-b). Benzamide derivatives $(8 a-c)$ were prepared via the reaction of compound (1a) with aniline derivatives, such as (p-toluidine, o-nitroaniline and m-nitroaniline). In a regioselective reaction 1,4-disubstituted-1,2,3triazole derivative (9a-j) were synthesized via the click reaction of compounds $4 a, 5 a$ and $(8 a-c)$ with benzyl azide and p-bromobenzyl azide. The compounds were identified using the spectral methods shown in the work. Cytotoxic effects of some final prepared compounds were studied in one cultured cellular models (MCF7 cell line) breast cancer (at various concentrations) by MTT assay, compound (9j) showed the better cytotoxic activity among the tested compounds.
\end{abstract}

Keywords: Oxadiazole, Aza- $\beta$-lactam, 1,2,3-Triazole, Click Chemistry, Cytotoxicity.

\section{INTRODUCTION}

A wide ranging of various heterocyclic compounds has been discovered to develop pharmaceutically essential molecule. Among them which have played a significant role in medical chemistry were oxadiazoles derivatives ${ }^{1,2}$. Which has been commonly used as a privileged scaffold for producing different novel pharmaceutical drug such as: antitumor ${ }^{3}$, anti-cancer agents ${ }^{4}$ and anti prostate $^{5}$, furthermore, oxadiazole derivatives which have thioamide group CNS. Its importance lies in eliminating the poisons in much of medicine used by human beings ${ }^{6}$. Azetidinones are one of

This is an Open Access article licensed under a Creative Commons Attribution-Non Commercial-Share Alike 4.0 International License (https://creativecommons.org/licenses/by-nc-sa/4.0/), which permits unrestricted Non Commercial use, distribution and reproduction in any medium, provided the original work is properly cited. 
the heterocyclic derivatives, which are utilized as synthase for various biologically active compounds ${ }^{7}$, as well as their recognition as antibacterial ${ }^{8}$, anti-inflammatory ${ }^{9}$ and anti-hepatitis ${ }^{10}$. The triazole derivatives classified as very important heterocycles compound, over past few years they have acquired in interest by introduce the "click chemistry concept" 11-12. In which this (process) has concentrate on reaction between high reactives partner that was providing access to structure which easy varied. Huisgen's thermal-cycloaddition of azide-alkyne obtain triazole $^{13}$, which catalyze by $\mathrm{Cu}(\mathrm{I})^{14-18}$ scheme (1). These situations describe "click" concept perfectly. This obtained 1,4-disubstituted regioisomer of 1,2,3-triazole and facilitate reaction at lesser temperature. In which increasing number of applications of Click chemistry was now being used in various researches such organic chemistry, bioconjugation ${ }^{19}$, drug discovery ${ }^{20}$, polymers ${ }^{21-22}$, and radiochemistry ${ }^{23}$.

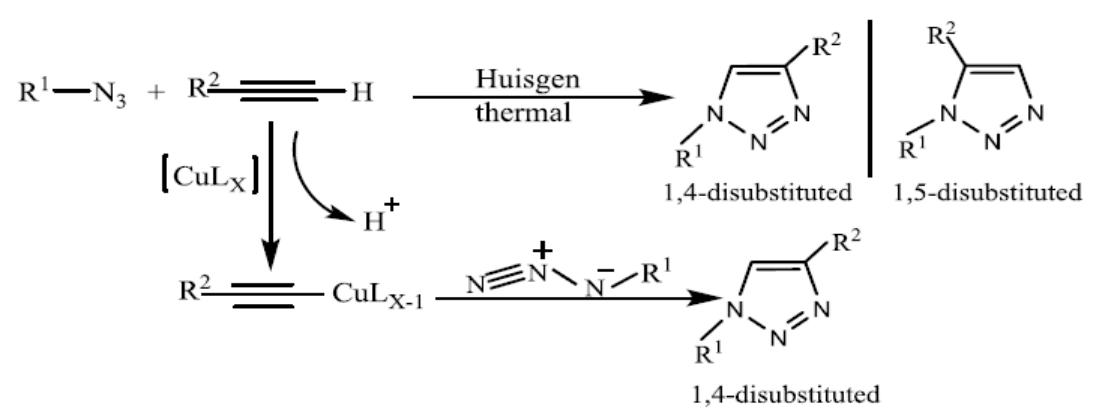

Scheme 1. Huisgen's cycloaddition to prepare 1,4-disubstituted-1,2,3-triazoles

\section{EXPERIMENTAL METHODS}

All chemicals were purchased from Fluka, $\mathrm{BDH}$ and Merck. M. p. is recorder use electrothermal (m.p) apparataus. The FT-IR spectral data were recorded on a Shimadzu FT-IR8400S spectrophotometer in the Department of Chemistry, College of Science, University of Baghdad. ${ }^{1} \mathrm{H}-\mathrm{NMR}$ and ${ }^{13} \mathrm{C}$-NMR spectra are recorder on central laboratory of Isfahan University and Sharif University of technology, $400 \mathrm{MHz}$, using $\mathrm{CDCl}_{3}$ or DMSO and tetramethylsilane (TMS) as an internal standard.

\section{Synthesis of ethyl-o-(N-Propargyl) sulfoamido benzoate $(2 a)^{24}$}

To a solution of o-(N-propargyl) sulfonamido benzoic acid (1a) (0.5 gm, 0.004 mole) in absolute ethanol (30 $\mathrm{ml})$, was added with stirring conc. sulfuric acid $(2 \mathrm{ml})$ the reaction mixture was refluxed for $8 \mathrm{~h}$, then the mixture was concentrated and neutralized by $\mathrm{NaHCO}_{3}$. The white precipitate that formed was filtered and re-crystallized from ethanol to give compound (2a). Yield 61\%, m.p.(110-112 $\left.{ }^{\circ} \mathrm{C}\right)$, IR- $\mathrm{KBr}$ $\mathrm{cm}^{-1}$ : 3274 (C-H) Acetylinic, 2125 (C C), 1737(C=O), 1056 (C-O) Ester. ${ }^{1} \mathrm{H}-\mathrm{NMR}$ (DMSO-d $)(\delta \mathrm{ppm}) 1.4$ (s, $3 \mathrm{H}, \mathrm{CH}_{3}$ ), 2.45(s, $1 \mathrm{H}, \mathrm{CH}$ acetylinic), 3.95(s, $2 \mathrm{H}$, $\left.\mathrm{CH}_{2}\right), 4.55\left(\mathrm{O}-\mathrm{CH}_{2}\right), 7.3 .94(\mathrm{~s}, 1 \mathrm{H}, \mathrm{NH}-\mathrm{C}=\mathrm{O}), 7.65-8.2$ (m, $4 \mathrm{H}, \mathrm{Ar}-\mathrm{H})$.

\section{Synthesis of o-(N-Propargyl) sulfoamido benzohydrazide $(3 a)^{25}$}

Ethyl-o-(N-Propargyl) sulfoamido benzoate (2a) (0.5 gm, 0.004 mole) was dissolved in (20 ml) absolute ethanol, ( 0.05 mole) of hydrazine hydrate was added and refluxed 4 hours. After cooling, white precipitate was formed and re-crystallized from EtOH to obtain compound (3a). Yield $70 \%$, m. p. $78-80^{\circ} \mathrm{C}$, IR-(KBr) cm-1 : 3330-3242 $\mathrm{NHNH}_{2}, 1656-1625(\mathrm{C}=\mathrm{O})$ amide. ${ }^{1} \mathrm{H}-\mathrm{NMR}$ (DMSO-d $\mathrm{d}_{6}$ ( $\left.\delta \mathrm{ppm}\right) 1.45\left(\mathrm{~s}, 2 \mathrm{H}, \mathrm{NH}_{2}\right)$, 2.98(s, $1 \mathrm{H}, \mathrm{CH}$ acetylinic), 3.91(s, $\left.2 \mathrm{H}, \mathrm{CH}_{2}\right), 5.94$ (s, $1 \mathrm{H}, \mathrm{NH}-\mathrm{C}=\mathrm{O})$, 7.54-7.86 (m, 4H, Ar-H).

\section{Synthesis of o-(5-mercapto-1,3,4-oxadiazol-2-yl)-} $\mathrm{N}$-propargyl benzene sulfonamide $(4 \mathrm{a})^{26}$

A mixture of Compound ( $3 \mathrm{a})$ (0.5 gm, 0.002 mole), with (0.004 mole) carbon disulfide and potassium hydroxide ( $0.2 \mathrm{gm}, 0.003$ mole) was dissolved in (15 $\mathrm{ml}) \mathrm{EtOH}$ and refluxed $7 \mathrm{~h}$, then the solvent is evaporate and water was added into the residue until it dissolved and acidify with dilute $(\mathrm{HCl})$, the precipitate is filtered, and washing with $\mathrm{H}_{2} \mathrm{O}$ to give compound (4a). Yield $83 \%$, m.p $119-120^{\circ} \mathrm{C}$, IR $(\mathrm{KBr}) \mathrm{cm}^{-1}:$ 3195(N-H), 2650(S-H), $1596 \mathrm{C}=\mathrm{N} .1 \mathrm{H}$ NMR (DMSO-d $\mathrm{d}_{6}$ ( $\left.\delta \mathrm{ppm}\right)$ 2.82(s, $1 \mathrm{H}, \mathrm{CH}$ acetylinic), $3.45\left(\mathrm{~s}, 1 \mathrm{H}, \mathrm{NH}-\mathrm{SO}_{2}\right), 3.8\left(\mathrm{~s}, 2 \mathrm{H}, \mathrm{CH}_{2}\right), 7.80-8.03$ (m, 4H, Ar-H). 
Synthesis of N-Propargyl-o-[Nl-sulfamido benzoyl] hydrazine carboxamide $(5 a)^{27}$

A mixture of o-(N-Propargyl) sulfoamido benzohydrazide (3a) (0.5gm, 0.002 mole) and $\mathrm{Ph}=\mathrm{C}=\mathrm{O}$ (0.002 mole) was refluxed in absolute ethanol $(15 \mathrm{ml})$ for 6 hours. After cooling the formed white precipitate was filtered, dried then re-crystallized from (1:1) $\mathrm{EtOH}$ and $\mathrm{DMF}$, for giving compound (5a). Produce $85 \%$, m.p. $134-136^{\circ} \mathrm{C}$, IR $\mathrm{cm}^{-1}:$ 3298(N-H), 1672(C=O). ${ }^{1} \mathrm{H}-\mathrm{NMR}: 3.09$ (s, $1 \mathrm{H}$, $\mathrm{CH}$ acetylinic), 3.91(s, 2H, $\left.\mathrm{CH}_{2}\right), 7.4-8.33(\mathrm{~m}, 10 \mathrm{H}$, Ar- $\mathrm{H}$ and $\left.\mathrm{SO}_{2}-\mathrm{NH}\right), 9.30(\mathrm{~s}, 1 \mathrm{H}, \mathrm{NH})$.

\section{General method to synthesis Schiff's bases $(6 a-b)^{28}$} o-(N-Propargyl) sulfoamido benzohydrazide (3a) (0.5 gm, 0.002 mole) was dissolved In $(20 \mathrm{ml})$ absolute EtOH. Aromatic aldehydes namely 2,4-dimethoxybenzaldehyde and p-hydroxybenzaldehyde,(2-3) drops of glacial (acetic acid) were added and refluxed 5 hours. The forming precipitate after-cooling was filtered and re-crystallized from $\mathrm{EtOH}$ to give compounds (6a-b).

\section{o-[(N-Propargyl)sulfamoyl]-N-(2,4-dimethoxybenzaldine) benzamide(6a)}

Yielding $85 \%$, m.p. $160-163^{\circ} \mathrm{C}, \mathrm{IR} \mathrm{cm}^{-1}$ : 3130(N-H), 1614(C=N), 1207 C-O. ${ }^{1} \mathrm{H}-\mathrm{NMR}$ (DMSO$\left.\mathrm{d}_{6}\right)(\delta \mathrm{ppm}): 2.05(\mathrm{~s}, 1 \mathrm{H}, \mathrm{CH}$ acetylinic), 3.7(s, 2H, $\mathrm{CH}_{2}$ ), 3.8(s, 6H, 2CH3-O), 5.97(s, $\left.1 \mathrm{H}, \mathrm{NH}-\mathrm{C}=\mathrm{O}\right)$, 6.54-8.46 (m, 8H, Ar-H), 9(CH=N).

\section{o-[(N-Propargyl)sulfamoyl]-N-(p-hydroxybenzaldine) benzamide(6b)}

Yielding 73\% m.p. $212-214^{\circ} \mathrm{C}$, IR- $\mathrm{KBr} \mathrm{cm}^{-1}$ : 3112(N-H), 1625(C=N), $3265(\mathrm{OH}) .{ }^{1} \mathrm{H}-\mathrm{NMR}: 2.1$ (s, $1 \mathrm{H}, \mathrm{CH}$ acetylinic), 3.8(s, $\left.2 \mathrm{H}, \mathrm{CH}_{2}\right), 6.04(\mathrm{~s}, 1 \mathrm{H}, \mathrm{NH}-$ $\mathrm{C}=\mathrm{O}), 7.3-8.1(\mathrm{~m}, 8 \mathrm{H}, \mathrm{Ar}-\mathrm{H}), 9.1(\mathrm{CH}=\mathrm{N}), 10(\mathrm{O}-\mathrm{H})$.

\section{General procedure for Synthesis of (Aza- $\beta$ -} lactam-derivative) (7a-b) ${ }^{29}$

A mixture of Schiff bases (7a-b) $(0.5$ gm, 0.002 mole) and $\mathrm{Ph}=\mathrm{C}=\mathrm{O}$ (0.002 mole) in $(15 \mathrm{ml})$ chloroform was refluxed 6 hours. The Solvent was removed and the residue treated through a mixture of (1:1) ethyl acetate-petroleum ether. The resultant ppt. was filtrated then dried to give compounds (7a-b).
N-[2-oxo-3-phenyl-4-[(2,4-dimethoxy)phenyl1,3-diazetidin-1-yl]-o-[(N-proparg yl) sulfamido] benzamide (7a)

Yield $85 \%$, m.p. $149-150^{\circ} \mathrm{C}, \mathrm{IR} \mathrm{cm}^{-1}: 3328$ (N-H), 1708 (C=O) Lactam, 1649 (C=O,Amide), $1232(\mathrm{C}-\mathrm{O})$.

N-[2-oxo-3-phenyl-4-[(p-hydroxy)phenyl-1,3diazetidin-1-yl]-0-[(N-propargyl)sulfamido] benzamide (7b)

Yield 78\%, m.p 161-162 ${ }^{\circ} \mathrm{C}, \mathrm{IR} \mathrm{cm}^{-1}: 3195$ $(\mathrm{N}-\mathrm{H}), 1712(\mathrm{C}=\mathrm{O})$ Lactam, 1649 (C=O)-Amide, $3315(\mathrm{H}-\mathrm{O})$.

\section{General-method to synthesized of benzamide} derivative $(8 a-c)^{30}$

Compound (1a) (0.5 gm, 0.002 mole), with (0.002 mole) of aniline derivatives such as ( $p$-toluidine, o-nitroaniline and m-nitroaniline) in $20 \mathrm{ml} \mathrm{POCl}_{3}$ was refluxed 4 hours. Then the mixture was Concentrated and poured on crushed ice with stirring for giving a solid mass. The product was filtered and dried to give compounds (8a-c).

o-[(N-Propargyl)sulfamoyl]-N-(p-tolyl)benzamide (8a):

Yielding 80\%, m.p. 99-101 oC, IR $\mathrm{cm}^{-1}$ : 3276(C-H)Acetylinic, 2130 (C C), 1735(C=O), ${ }^{1} \mathrm{H}-N M R: 2.12\left(\mathrm{~s}, 3 \mathrm{H}, \mathrm{CH}_{3}\right.$ ), 2.85(s, $1 \mathrm{H}, \mathrm{CH}$ acetylinic), 3.44(s,1H, NH-SO $)_{2}, 4.59\left(\mathrm{~s}, 2 \mathrm{H}, \mathrm{CH}_{2}\right), 6.5(\mathrm{~s}, 1 \mathrm{H}$, $\mathrm{NH}-\mathrm{C}=\mathrm{O}), 6.48-8.34(\mathrm{~m}, 8 \mathrm{H}, \mathrm{Ar}-\mathrm{H}) .{ }^{13} \mathrm{C}-\mathrm{NMR}$ ( $\delta \mathrm{ppm}):$ 27.46 $\left(\mathrm{CH}_{3}\right), 75-76(\mathrm{C} \mathrm{C}), 121-136$ (C-Ar), $158(\mathrm{C}=\mathrm{O})$.

o-[(N-Propargyl)sulfamoyl]-N-(m-nitrophenyl) benzamide (8b)

Yielding $76 \%$, m.p. $90-91^{\circ} \mathrm{C}, \mathrm{IR} \mathrm{cm}^{-1}$ : 3276(C-H) Acetylinic, 2127 (C C), 1737(C=O).

o-[(N-Propargyl)sulfamoyl]-N-(o-nitrophenyl) benzamide (8c):

Yield $74 \%$, m.p $96-97^{\circ} \mathrm{C}$, IR $\mathrm{cm}^{-1}: 3274$

(C-H) Acetylinic, 2125(C C), 1737(C=O).

\section{Preparation of alkyl azide (11 $^{31}$}

Sodium azide $(0.015$ mole) was added slowly to refluxed DMF $(25 \mathrm{ml})$, the reflux was continued until all the sodium azide dissolved then benzyl chloride and p-bromobenzyl bromide $(0.0075$ mole) was slowly added, the mixture then was heated 
overnight (temperature is fixed at $75^{\circ} \mathrm{C}$ ), after cooling (25 ml) of distilled $\mathrm{H}_{2} \mathrm{O}$ was added, $25 \mathrm{ml}$ of diethyl ether was also added and the organic-layer was extracted (the addition of diethyl ether was repeated three times), then the combined organic layers were dried using magnesium sulfate and evaporated under reduced pressure. To give the colorless liquids, n-benzyl azide $80 \%$ and p-bromobenzyl azide $83 \%$, IR $(\mathrm{KBr}) \mathrm{cm}^{-1}:$ 2096 $\left(\mathrm{N}_{3}\right)$.

General procedure of synthesis 1,4-disubstituted1,2,3-triazole derivatives $(9 a-j)^{31}$

A mixture of compounds $4 a, 5 a$ and (8a-c) (0.002 mole) was slowly added with stirring to a solution containing sodium ascorbate $(0.00045$ mole) and $\mathrm{CuSO}_{4} .5 \mathrm{H}_{2} \mathrm{O}(0.002$ mole $)$ in $(25 \mathrm{ml})$ DMF, then p-bromobenzyl azide and benzyl azide (0.005 mole) was added. The mixture then heated overnight (the temperature was fixed at $75^{\circ} \mathrm{C}$ ), after cooling $25 \mathrm{ml}$ of distilled water was added, $25 \mathrm{ml}$ of diethyl ether was also added to the mixture and the organic-layer was extracted (the addition of diethyl ether was repeated three times), then the combined organic-layers were dried over magnesium sulfate, the forming ppt. was filtered and dried to give compounds (9a-j).

o-(5-mercapto-1,3,4-oxadiazol-2-yl)-N-(1-benzyl1,2,3-triazol-4-yl)methyl benzene sulfonamide (9a) The product $80 \%$, m.p. $212-215^{\circ} \mathrm{C}$, IR $\mathrm{cm}^{-1}:$ 3338(N-H), 1618(N=N), 1164(C=S). ${ }^{1} \mathrm{H}-\mathrm{NMR}$ : 4.99 (s, $2 \mathrm{H}, \mathrm{CH}_{2}$ ), 5.58(s, $2 \mathrm{H}$, benzylic), 7.25-8.33 $\left(\mathrm{m}, 13 \mathrm{H}, \mathrm{Ar}-\mathrm{H}\right.$ and $\left.\mathrm{SO}_{2}-\mathrm{NH}\right), 11.77(\mathrm{~s}, 1 \mathrm{H}, \mathrm{SH})$. ${ }^{13} \mathrm{C}-\mathrm{NMR}(\delta \mathrm{ppm}): 31\left(\mathrm{NH}-\mathrm{CH}_{2}\right), 52(\mathrm{C}$-benzylic), 127-133 (C-Ar).

o-(5-mercapto-1,3,4-oxadiazol-2-yl)-N-(1-(pbromobenzyl-1,2,3-triazol-4-yl)) methyl benzene sulfonamide $(9 b)$

The product $66 \%$, m.p. $175-176^{\circ} \mathrm{C}$, IR $(\mathrm{KBr})$ $\mathrm{cm}-1$ : 3423(N-H), $1564(\mathrm{~N}=\mathrm{N}), 1161(\mathrm{C}=\mathrm{S})$.

o-[(N-1-benzyl-1,2,3-triazol-4-yl)]methyl sulfamido$\mathrm{N}$-phenyl benzoyl hydrazine carbamide (9c)

The product $65 \%$, m.p. $228-231^{\circ} \mathrm{C}$, IR $(\mathrm{KBr})$ $\mathrm{cm}^{-1}:$ 3471(N-H), 1720(C=O), $1562(\mathrm{~N}=\mathrm{N})$.

o-[(N-(1-(p-bromobenzyl))-1,2,3-triazol-4-yl)] methylsulfamido- $\mathrm{N}$-phenyl benzoyl hydrazine carbamide (9d)

The product $78 \%$, m.p. $180-183^{\circ} \mathrm{C}$, IR
$(\mathrm{KBr}) \mathrm{cm}^{-1}:$ 3409(N-H), $1708 \quad(\mathrm{C}=\mathrm{O}), 1596(\mathrm{~N}=\mathrm{N})$, 757 (C-Br). ${ }^{1} \mathrm{H}-\mathrm{NMR}: 4.80\left(\mathrm{~s}, 2 \mathrm{H}, \mathrm{CH}_{2}\right.$ ), 5.41(s, 2H benzylic), 7.25-8.33(m, $15 \mathrm{H}, \mathrm{Ar}-\mathrm{H}$ and $\left.\mathrm{SO}_{2}-\mathrm{NH}\right)$, $9.30(\mathrm{~s}, 1 \mathrm{H}, \mathrm{NH}) .{ }^{13} \mathrm{C}-\mathrm{NMR}(\delta \mathrm{ppm}): 45\left(\mathrm{NH}-\mathrm{CH}_{2}\right)$, 60(C- benzylic), 121-138(C-Ar), 153-166(C=O).

o-[N-(1-benzyl)-1,2,3-triazol-4-yl]methylsulfamoyl -N-(p-tolyl)benzamide(9e)

Yielding $80 \%$, m.p. $198-199^{\circ} \mathrm{C}$, IR-KBr cm${ }^{-1}$ : $3452(\mathrm{~N}-\mathrm{H}), 1726(\mathrm{C}=\mathrm{O}), 1596(\mathrm{~N}=\mathrm{N})$.

o-[N-(1-(p-bromobenzyl))-1,2,3-triazol-4-yl] methylsulfamoyl-N-(p-tolyl) benzamide (9f)

Yielding $75 \%$, m.p. $164-165^{\circ} \mathrm{C}$, IR $\mathrm{cm}^{-1}$ : 3422(N-H), 1724(C=O), 1595(N=N), 586(C-Br). ${ }^{1} \mathrm{H}-\mathrm{NMR}: 2.21\left(\mathrm{~s}, 3 \mathrm{H}, \mathrm{CH}_{3}\right), 5\left(\mathrm{~s}, 2 \mathrm{H}, \mathrm{N}-\mathrm{CH}_{2}\right), 5.48$ (s, 2H, benzylic), 7.25-8.33(m, $13 \mathrm{H}, \mathrm{Ar}-\mathrm{H}$ and $\mathrm{SO}_{2}-$ $\mathrm{NH}) \cdot{ }^{13} \mathrm{C}-\mathrm{NMR}(\delta \mathrm{ppm}): 28\left(\mathrm{CH}_{3}\right), 33\left(\mathrm{NH}-\mathrm{CH}_{2}\right), 52$ (C-benzylic), 121-136(C-Ar), 158(C=O).

o-[N-(1-benzyl)-1,2,3-triazol-4-yl]methylsulfamoyl - $\mathrm{N}$-(m-nitrophenyl) benzamide $(9 \mathrm{~g})$

The product $70 \%$, m.p. $180-181^{\circ} \mathrm{C}, \mathrm{IR} \mathrm{cm}^{-1}$ : 3419(N-H), 1731(C=O), 1595(N=N), (1535) asym. (1336) sym. $\mathrm{NO}_{2}$.

o-[N-(1-(p-bromobenzyl))-1,2,3-triazol-4-yl]methyl sulfamoyl-N-(m-nitrophenyl)benzamide (9h):

The product $72 \%$, m.p. $150-151^{\circ} \mathrm{C}, \mathrm{IR} \mathrm{cm} \mathrm{cm}^{-1}$ : 3390(N-H), $1722(\mathrm{C}=\mathrm{O}), 1595(\mathrm{~N}=\mathrm{N}),(1539)$ asym. (1325) sym. $\mathrm{NO}_{2} \cdot{ }^{1} \mathrm{H}-\mathrm{NMR}: 4.99$ (s, 2H, N-CH${ }_{2}$ ), 5.58(s, 2H,benzylic), 7.25-8.33 (m, 13H, Ar-H and $\left.\mathrm{SO}_{2}-\mathrm{NH}\right) \cdot{ }^{13} \mathrm{C}-\mathrm{NMR}(\delta \mathrm{ppm}): 33\left(\mathrm{NH}-\mathrm{CH}_{2}\right), 52$ (C-benzylic), 121-136 (C-Ar), 158(C=O).

o-[N-(1-benzyl)-1,2,3-triazol-4-yl]methylsulfamoyl-N(o-nitrophenyl) benzamide (9i)

The product $70 \%$, m.p. $188-189^{\circ} \mathrm{C}, \mathrm{IR} \mathrm{cm}^{-1}$ : 3440(N-H), 1726(C=O), 1627( $\mathrm{N}=\mathrm{N}),(1460)(1330)$ $\mathrm{NO}_{2}$ (asym.) (sym.). ${ }^{1} \mathrm{H}-\mathrm{NMR}: 4.99\left(\mathrm{~s}, 2 \mathrm{H}, \mathrm{N}-\mathrm{CH}_{2}\right)$. 5.58(s, 2H, benzylic), 7.25-8.33(m, 13H, Ar-H and $\left.\mathrm{SO}_{2}-\mathrm{NH}\right) \cdot{ }^{13} \mathrm{C}-\mathrm{NMR}(\delta \mathrm{ppm}): 33\left(\mathrm{NH}-\mathrm{CH}_{2}\right), 52$ (C-benzylic), 121-136 (C-Ar), 158(C=O).

o-[N-(1-(p-bromobenzyl))-1,2,3-triazol-4-yl] methylsulfamoyl- $\mathrm{N}$-(o-nitrophenyl) benzamide (9j)

The product $68 \%$, m.p. $158-159^{\circ} \mathrm{C}, \mathrm{IR} \mathrm{cm}^{-1}$ : 3407(N-H), 1722(C=O), 1593(N=N), (1560) (1325) $\mathrm{NO}_{2}$ (asym.) (sym.). 


\section{In vitro Cell viability Assay (MTT) ${ }^{32}$}

The cytoxicity profiles were estimated by using "3-[4,5-dimethyl-thiazol-2-yl]- 2,5-diphenyltetrazolium bromide" (MTT) microculture, tetrazolium viability-method. To prepare stock solution we dissolve the compounds in DMSO and sequential dilution $(12.5 \mu \mathrm{g} / \mathrm{ml}-200 \mu \mathrm{g} / \mathrm{ml})$ were prepared through dissolving stock-solutions in cualturecellular modelas (MCF-7 cell line) breast-cancer. At the exact time in which after compounds (4a, $6 \mathrm{a}$ and $8 \mathrm{f}$ ) treatment, MTT (5 mg/mL) was added in each wells and incubation of plate are 4 hours. After removing the media, DMSO is add into each well for solubilized formazan-crystals. The same method is returned but using WRL-68 normal cell (liver cell) as negative control. Absorbance was measured at wavelength $(575 \mathrm{~nm})$ using (Hidex Chamealon platereader). Perceantage of cellularviabilities were calculated with suitable control take into account. The concentration that inhibition 50\% of cell-growth $\left(\mathrm{IC}_{50}\right.$ value) is determined. All-tests are executed in triplicate. Percentage viability of cells exposed to various treatments was obtained as follows: cell Viability $\%=($ Absorbance treated sample/ Absorbance of non-treated sample) $\times 100$ (Non-treated cultures in all experiments contained the medium only).

\section{RESULTS AND DISCUSSION}

The synthesized of Oxadiazole, Aza- $\beta$ lactam and 1,2,3-triazole derivatives were achieved by starting from compound (1a) that react with absolute ethanol, in the presence concentrated
$\mathrm{H}_{2} \mathrm{SO}_{4}$ gave compound (2a) that have been reacted with $80 \%$ hydrazine hydrate to give o-(N-propargyl) sulfonamido benzohydrazide (3a). The absence of $\left(\mathrm{C}=\mathrm{O}\right.$ ester) stretching-band at $(1737) \mathrm{cm}^{-1}$ and the presence of new stretching-bands, at (32423330) $\mathrm{cm}^{-1}$ and $1656 \mathrm{~cm}^{-1}$ that due to $\left(\mathrm{NH}-\mathrm{NH}_{2}\right)$ and $(\mathrm{C}=\mathrm{O}$ amide) respectively are attributed to the formation of benzohydrazide derivative (3a), while ${ }^{1} \mathrm{H}$-NMR spectrum Fig. (1) showed absence of signals $1.4 \mathrm{ppm}\left(\mathrm{CH}_{3}\right), 4.55 \mathrm{ppm}\left(\mathrm{O}-\mathrm{CH}_{2}\right)$, and appearance of signals at $1.45 \mathrm{ppm}\left(\mathrm{NH}_{2}\right), 5.94 \mathrm{ppm}$ $(\mathrm{NH}-\mathrm{C}=\mathrm{O})$ ppm. Cyclization of $(3 \mathrm{a})$ with $\left(\mathrm{CS}_{2}\right)$ in presence $(\mathrm{KOH})$ give 1,3,4-oxadiazole compound (4a) (scheme 2). Absence of stretching bands at (3242-3330) $\mathrm{cm}^{-1}$ for $\left(\mathrm{NH}-\mathrm{NH}_{2}\right)$ and $(1656) \mathrm{cm}^{-1}$ for ( $\mathrm{C}=\mathrm{O}$ amide) and presence weak stretching band of $\mathrm{SH}(2650) \mathrm{cm}^{-1}$ and stretching band $(\mathrm{C}=\mathrm{N})(1596)$ $\mathrm{cm}^{-1}$ is attributed to the formation compound (4a), while ${ }^{1} \mathrm{H}-\mathrm{NMR}$ of compound (4a) Fig. (2) display the following characteristic signals $\delta(\mathrm{ppm}): 2.82(\mathrm{~s}, 1 \mathrm{H}$, $\mathrm{CH}$ acetylinic), 3.8 (s, 2H, $\left.\mathrm{CH}_{2}\right), 7.8-8.03(\mathrm{~m}, 4 \mathrm{H}$, $\mathrm{Ar}-\mathrm{H}), 8.2\left(\mathrm{~s}, 1 \mathrm{H}, \mathrm{NH}-\mathrm{SO}_{2}\right)$. The reaction of compound (3a) with phenyl isocyanate to give compound (5a). The product was identified by FT.IR spectrum which shows absence of stretching band of $\left(\mathrm{NH}-\mathrm{NH}_{2}\right)$ at (3242- 3330) $\mathrm{cm}^{-1}$ and existence of new absorption bands due to $(\mathrm{NH})$ at $(3220) \mathrm{cm}^{-1}$ and $(\mathrm{C}=\mathrm{O})$ at $(1672)$ $\mathrm{cm}^{-1}$. Schiff-bases (6a-b) were synthesized by condensation of hydrazine derivative ( $3 a$ ) with various aromaticaldehydes (2,4-dimethoxybenzaldehyde and p-hydroxybenzaldehyde) with few drops of (glacialacetic acid). The absence of $\left(\mathrm{NH}_{2}\right)$ stretching bands

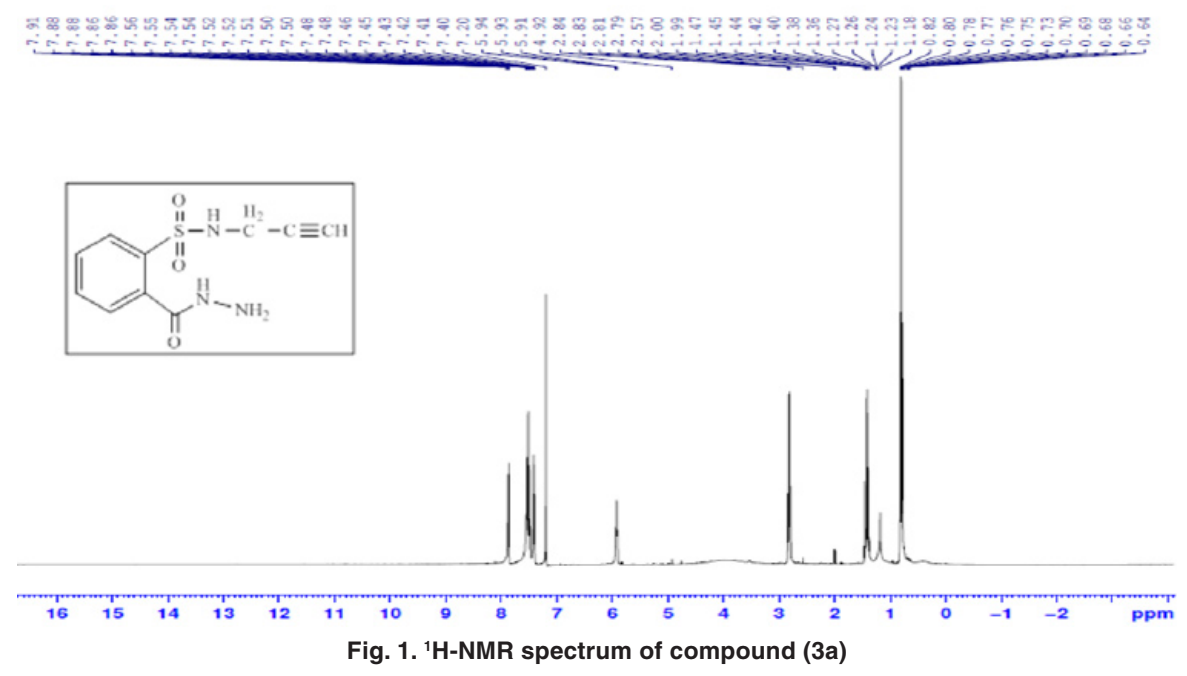




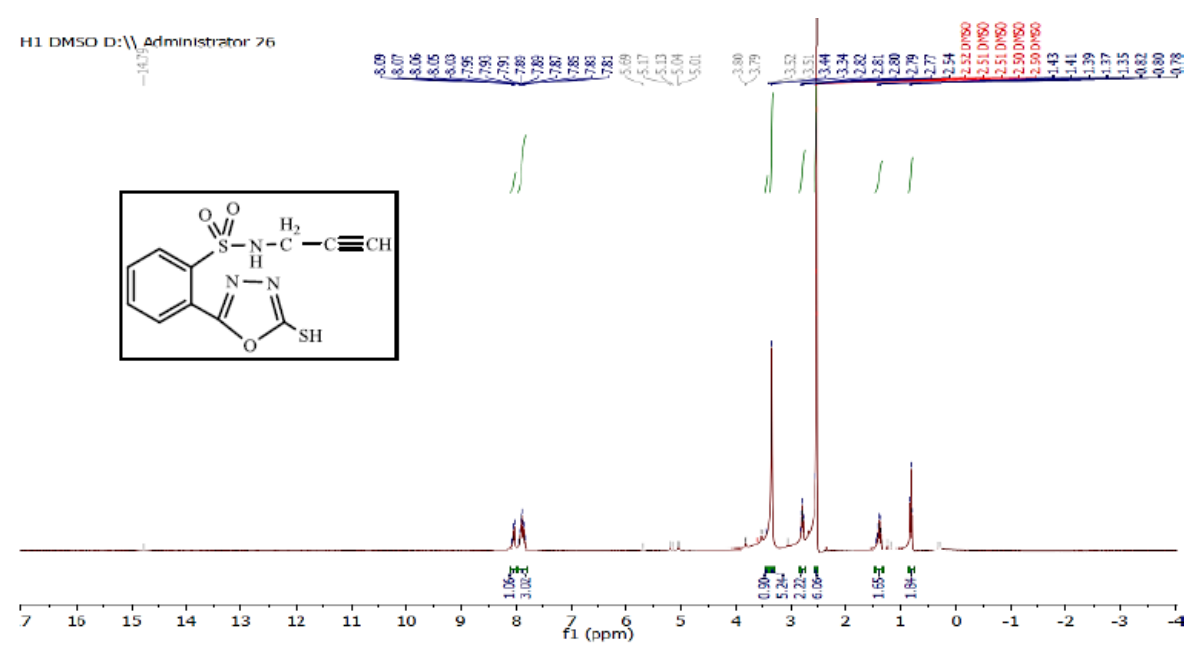

Fig. 2. ${ }^{1} \mathrm{H}$-NMR spectrum of compound (4a)

at $(3242-3330) \mathrm{cm}^{-1}$ and appearance $(\mathrm{C}=\mathrm{N})$ stretching band at (1596-1602) $\mathrm{cm}^{-1}$ indicate the formation of Schiff-bases, while ${ }^{1} \mathrm{H}$-NMR spectrum showed singlet signal for $(\mathrm{CH}=\mathrm{N})$ at $9.1 \mathrm{ppm}$. Moreover, The cyclization of (6a-b) with phenyl isocyanate via [2+2] cycloaddition reaction gave the corresponding " $1,3-$ diazetidine-2-one (Aza- $\beta$-lactam)" (7a-b) derivatives. The disappearance of stretching band of $(\mathrm{CH}=\mathrm{N}-)$ at (1614-1625) $\mathrm{cm}^{-1}$ and appearance stretching band of $(\mathrm{C}=\mathrm{O}$ aza- $\beta$-lactam $)$ at $(1708-1712) \mathrm{cm}^{-1}$ were utilized to confirm the compounds. Benzamide derivatives (8a-c) were synthesized by condensation compound (2a) with aniline derivatives such as ( $p$-toluidine, o-nitroaniline and m-nitroaniline) in presence $\mathrm{POCl}_{3}$. The absence of absorption band of $(\mathrm{O}-\mathrm{H})$ at (3309) $\mathrm{cm}^{-1}$, and appearance absorp. band of ( $\mathrm{C}=\mathrm{O}$ amide) at (1735-1737) $\mathrm{cm}^{-1}$ gave good evidence for formation. While $1 \mathrm{H}-\mathrm{NMR}$ spectrum of compound 8a Fig. (3) showed appearance of signals at $2.85 \mathrm{ppm}(\mathrm{CH}$ acetylinic), $6.5 \mathrm{ppm}(\mathrm{NH}-\mathrm{C}=\mathrm{O})$, the ${ }^{13} \mathrm{C}-\mathrm{NMR}$ of compound 8a Fig. (4) display $27.46\left(\mathrm{CH}_{3}\right), 75-76$ (C C), 121-136 (C-Ar), $158(\mathrm{C}=\mathrm{O})$.

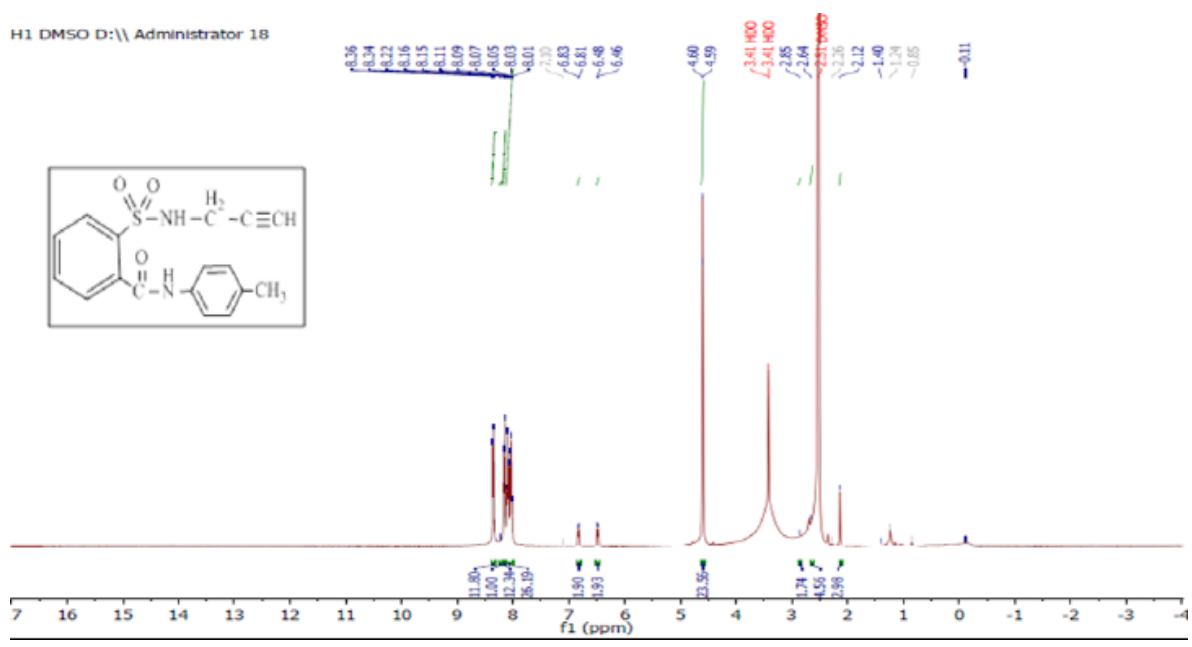

Fig. 3. ${ }^{1} \mathrm{H}$-NMR spectrum of compound (8a)

1,4-disubsituted-1,2,3-triazole derivatives

(9a-j) (scheme 3) were prepared under click conditions by refluxing compounds $4 \mathrm{a}, 5 \mathrm{a}$ and (8a-c) with (benzyl and p-bromobenzyl) azide. Disappearance of absorption bands at (3274-3298) $\mathrm{cm}^{-1}$ for acetylenic C-H, (2125-2127) $\mathrm{cm}^{-1}$ for C C and $2096 \mathrm{~cm}^{-1}$ for azide group and appearance of new band for $(\mathrm{N}=\mathrm{N})$ at $(1626-1562)$. While ${ }^{1} \mathrm{H}-\mathrm{NMR}$ and ${ }^{13} \mathrm{C}$-NMR spectra of compounds (9a), (9f), (9h) and (9i) exhibit the absence of singlet signal at (2.8) 
ppm due to (C-H) acetylenic Fig. (5),(6),(8),(10) and disappearance of the signal at (75-76) ppm due to (C

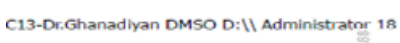

C13-Dr.Ghanadiyan DMSO D: II Administrator 18

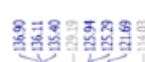

C) Fig. (7),(9),(11) is good evidence for the formation of the 1,2,3-triazole derivatives.

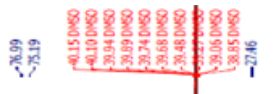

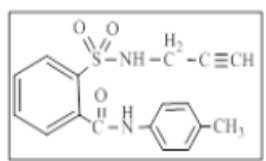

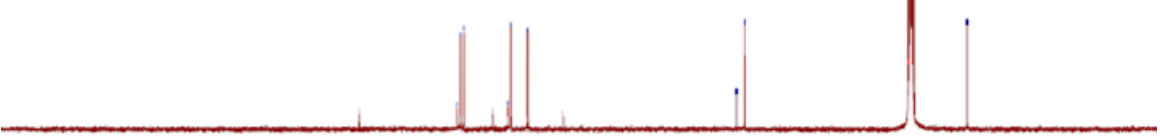

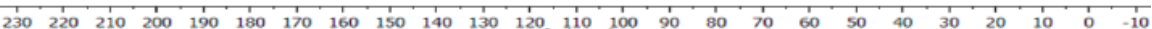

Fig. 4. ${ }^{13} \mathrm{C}-\mathrm{NMR}$ spectrum of compound (8a)

Taskhiri-Zahra-EN960615-293..314.30.1.1r

K6 DMSO D: 11 Administrator 14

(1)
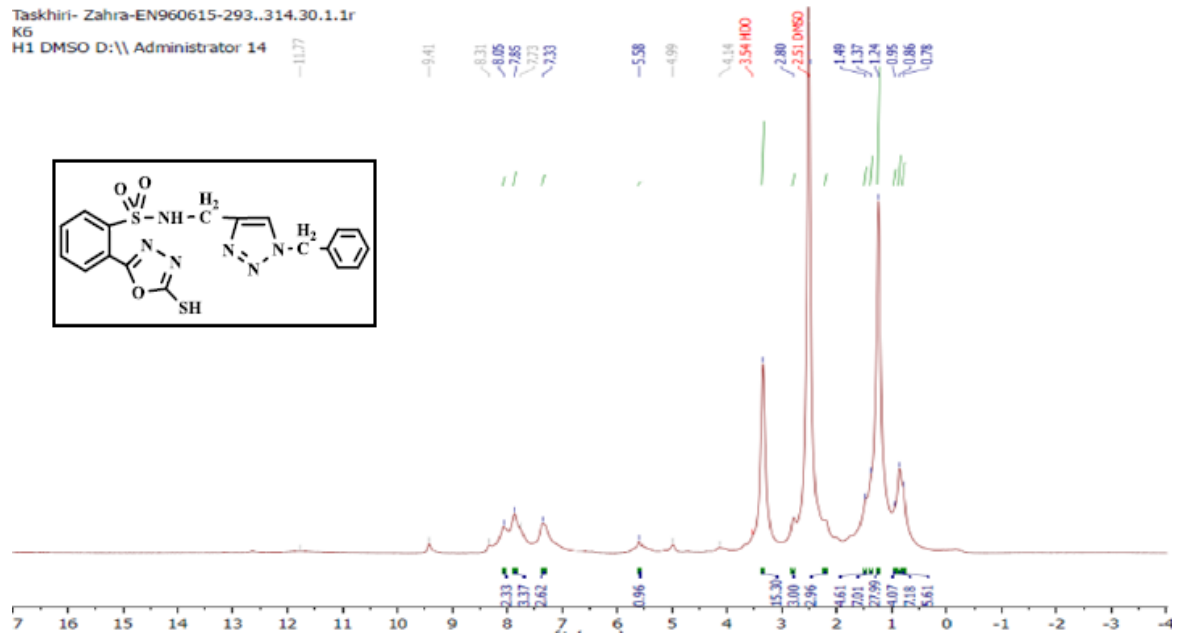

Fig. 5. ${ }^{1} \mathrm{H}-\mathrm{NMR}$ spectrum of compound (9a)

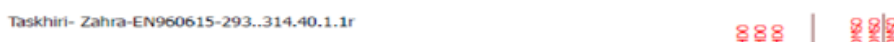

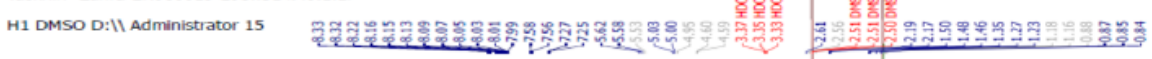
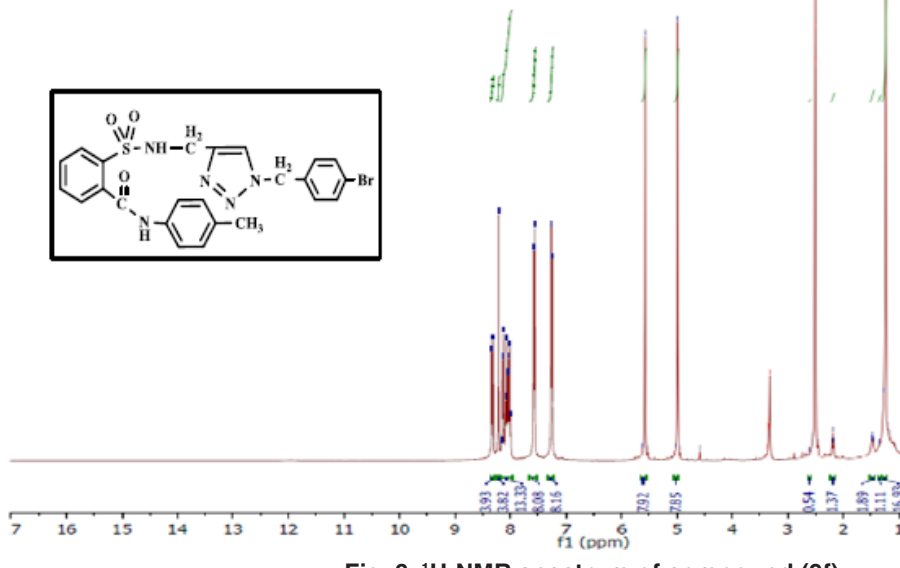

Fig. 6. ${ }^{1} \mathrm{H}-\mathrm{NMR}$ spectrum of compound (9f) 
Taskhiri- Zahra-EN960615-293..314.41.1.1r

C13-Dr.Ghanadiyan DMSO D:II Administrator F5.

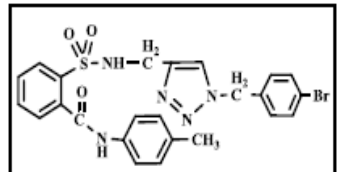
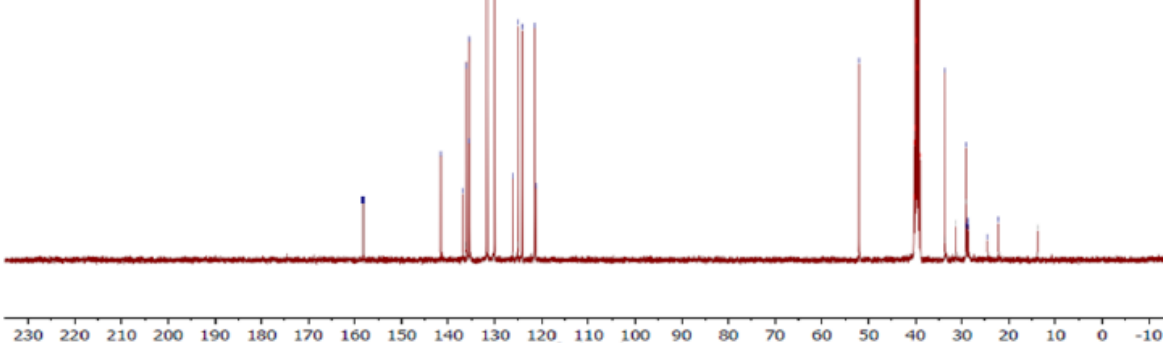

Fig. $7 .{ }^{13} \mathrm{C}-\mathrm{NMR}$ spectrum of compound (9f)

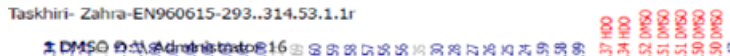

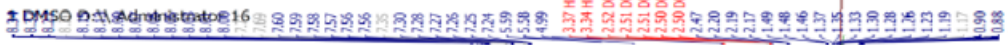

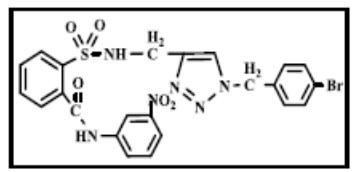

I|l
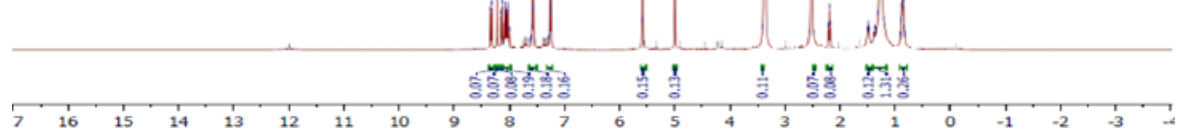

Fig. 8. ${ }^{1} \mathrm{H}-\mathrm{NMR}$ spectrum of compound (9h)

Taskhiri- Zahra-EN960615-293..314.51.1.1r

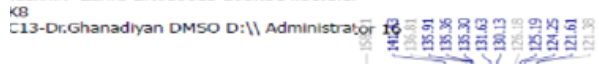
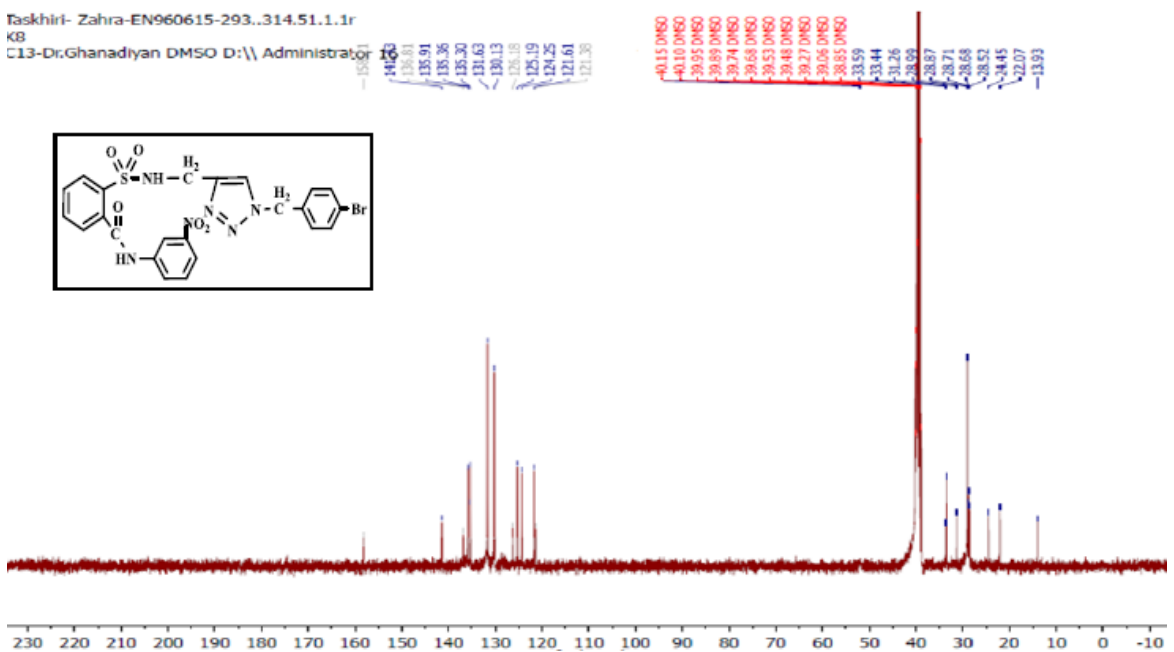

Fig. $9 .{ }^{13} \mathrm{C}-\mathrm{NMR}$ spectrum of compound (9h) 


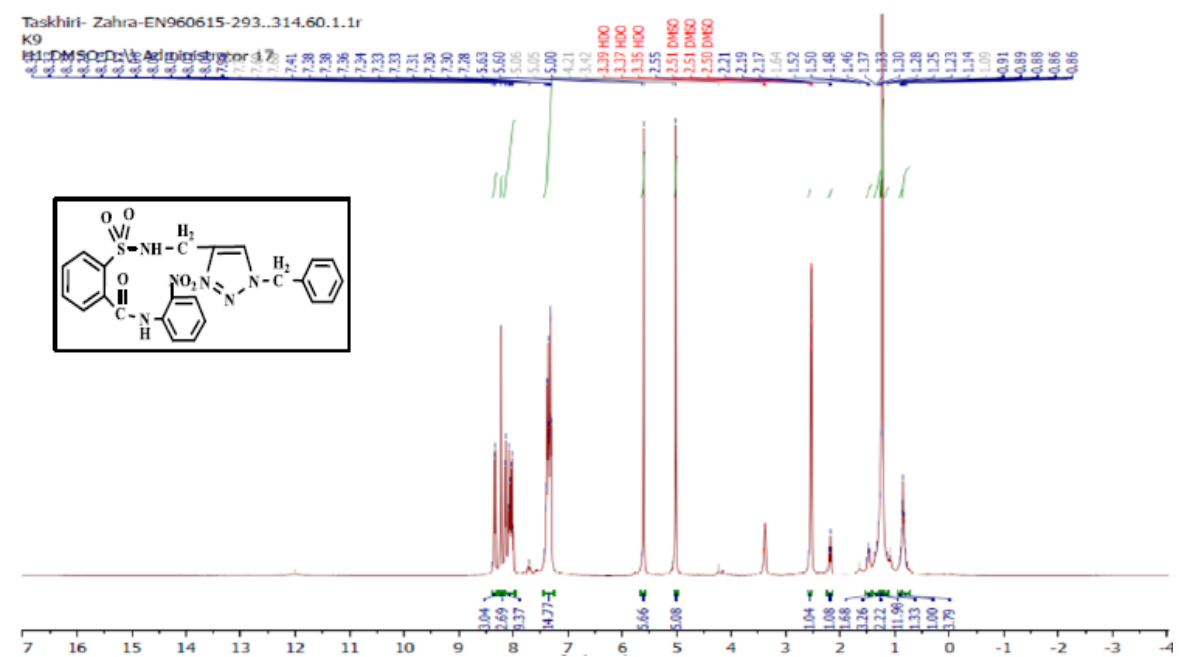

Fig. 10. ${ }^{1} \mathrm{H}-\mathrm{NMR}$ spectrum of compound (9i)

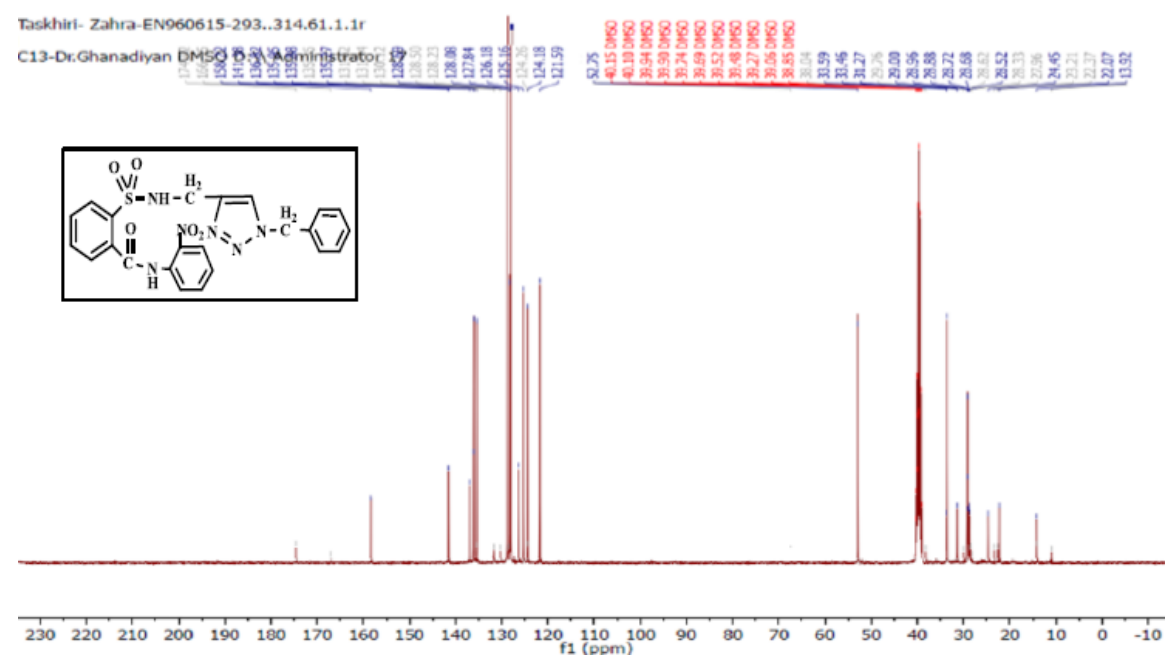

Fig. $11 .{ }^{13} \mathrm{C}-\mathrm{NMR}$ spectrum of compound (9i)

\section{In-vitro cytotoxic activity}

The results of cytotoxic activity of compounds (4a, 6a and 9j) on MCF7 cancer cell were represented in Table 1 and Fig. (12, 13 and 14) compared to normal cell line WRL-68 (liver cell) as negative control. The results showed that when we treated (MCF-7) cell with different concentrations
$(12.5-200 \mu \mathrm{g} / \mathrm{ml})$ the best inhibition was at $100 \mu \mathrm{g} / \mathrm{ml}$ by compound (12f) exhibited $71.66 \%$ of cancer cell death, with $\mathrm{IC}_{50}$ value $56.19 \mu \mathrm{g} / \mathrm{ml}$ while exhibited $9.61 \%$ of normal cell death. As we comparison with another studying of anticancer potential ${ }^{33}$ we find the best inhibition exhibited $51.4 \%$ at $100 \mu \mathrm{g} / \mathrm{ml}$ on MCF-7 cell line compared to $25 \mu \mathrm{g} / \mathrm{ml}$ doxorubicin as positive control so they didn't use normal cells.

Table 1: the anticancer activity of compounds $4 a, 6 a$ and 9 j on MCF7 cell line by MTT method Concentrations of comp. $(\mu \mathrm{g} / \mathrm{ml})($ Mean \pm SD)

\begin{tabular}{ccccccccccc}
\hline Cell lines & \multicolumn{3}{c}{ MCF-7 } & \multicolumn{9}{c}{ WRL-68 } \\
\hline Comp. no. & 200 & 100 & 50 & 25 & 12.5 & 200 & 100 & 50 & 25 & 12.5 \\
$4 \mathrm{a}$ & 66.09 & 40.81 & 6.58 & 0.16 & 2.69 & 35.77 & 7.51 & 1.19 & 2.57 & 0.69 \\
& \pm 8.21 & \pm 7.73 & \pm 6.45 & \pm 4.85 & \pm 2.74 & \pm 7.37 & \pm 4.45 & \pm 3.03 & \pm 0.89 & \pm 2.49 \\
$6 \mathrm{a}$ & 67.01 & 52.49 & 15.36 & - & - & 41.83 & - & 1.51 & 0.42 & 0.67 \\
& \pm 1.67 & \pm 9.80 & \pm 7.59 & & & \pm 12.46 & & \pm 2.68 & \pm 4.02 & \pm 4.75 \\
$9 j$ & 84 & 71.66 & 52.47 & 14.7 & 3.35 & 44.33 & 9.61 & 8.37 & 0.74 & 2.46 \\
& \pm 8.21 & \pm 4.79 & \pm 5.14 & \pm 3.57 & \pm 4.18 & \pm 23.82 & \pm 39 & \pm 7.29 & \pm 6.65 & \pm 18.36 \\
\hline
\end{tabular}




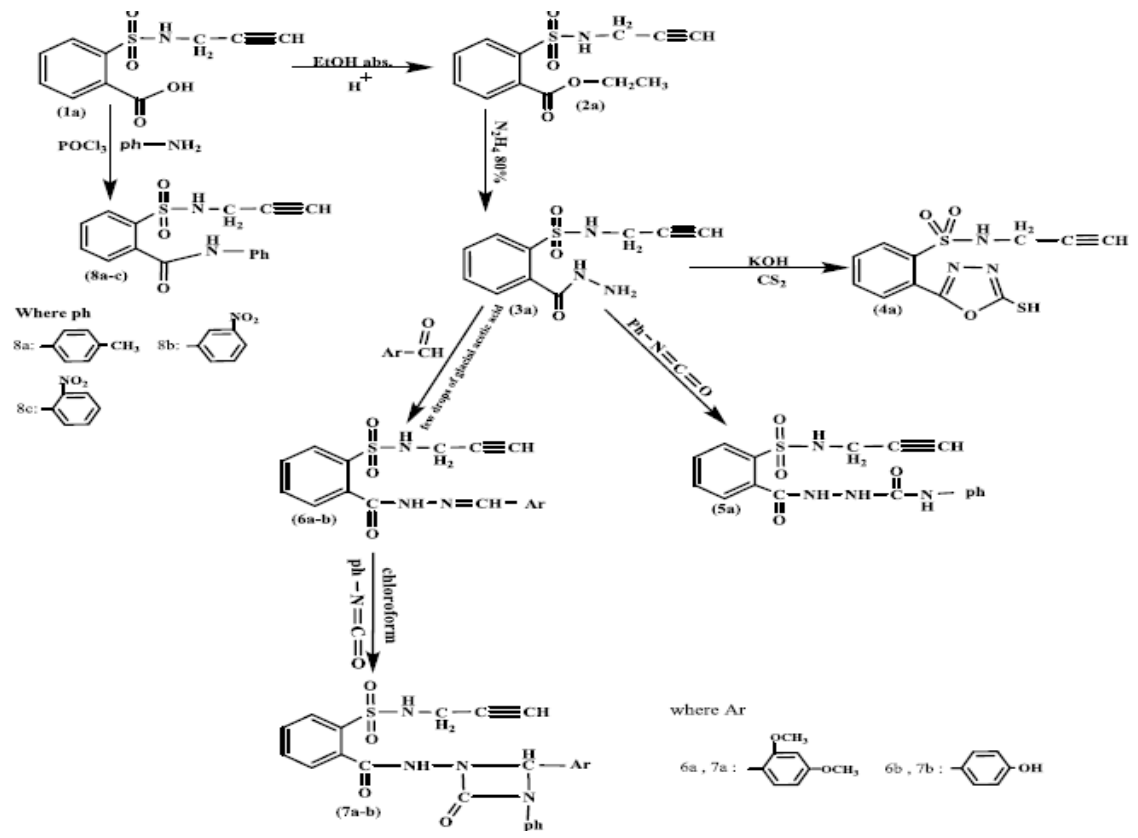

Scheme 2. Route of synthesized compounds (2a-5a),(6a-b),(7a-b) and (8a-c)
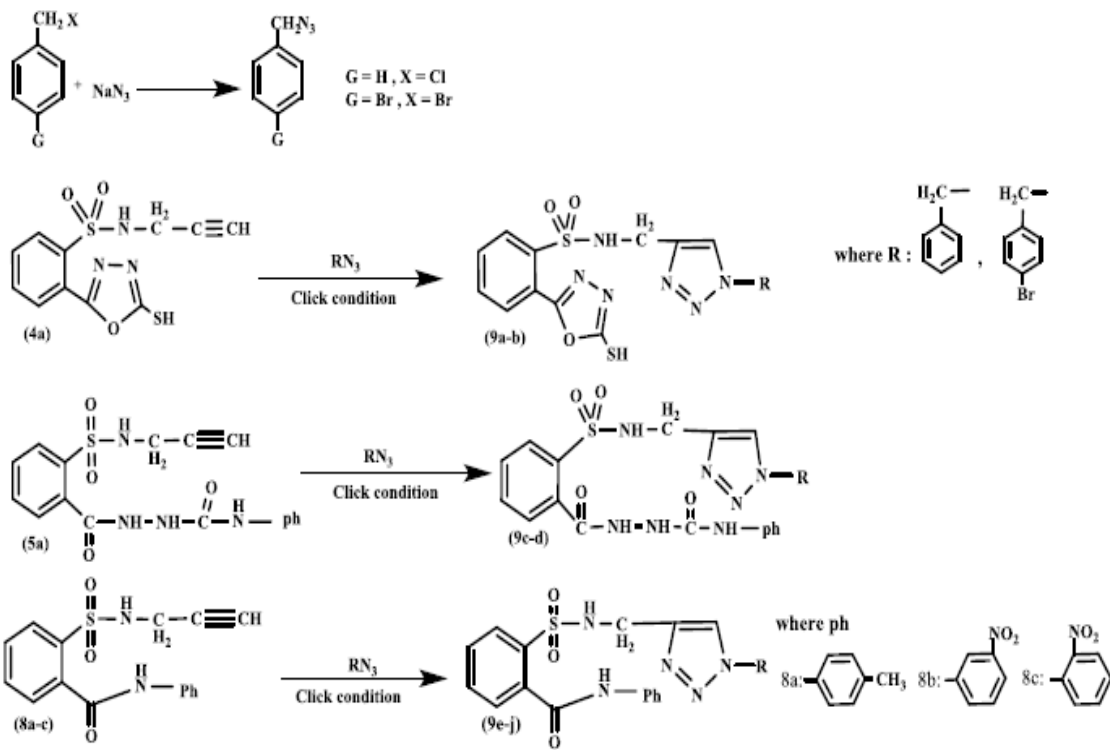

Scheme 3. Route of Synthesized compounds (9a-9j) via click reaction

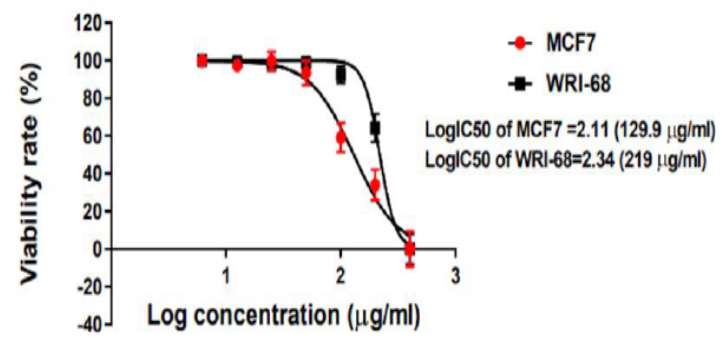

Fig. 12. The cytotoxic activity represented by viability rate of comp. (4a)
Normalize of Transform of dose vs. response

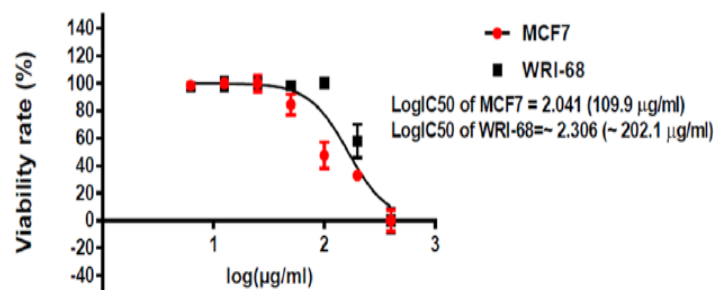

Fig. 13. The cytotoxic activity represented by viability rate of comp. (6a) 
Normalize of Transform of log-dose vs response

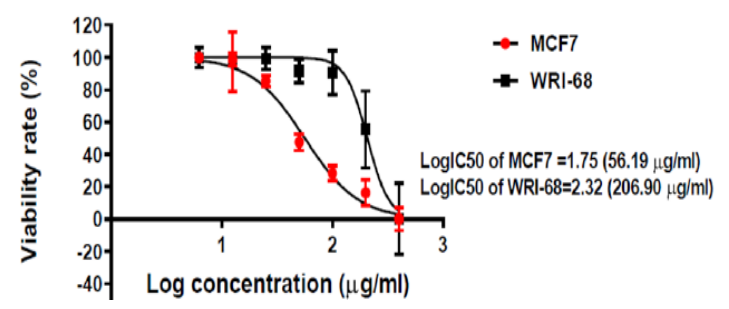

Fig. 14. The cytotoxic activity represented by viability rate of comp. (9j)

\section{CONCLUSION}

Some new oxadiazole, Aza- $\beta$-lactam derivatives were synthesized, and to obtained "1,4-disubstituted-1,2,3-triazole through click- chemistry". The studying of cytotoxicity activity on some final prepared compounds (4a, 6a and 9j) showed that tested compounds have a promising significant $(p \leq 0.05)$ cytotoxic activity. Compound 9 j showed the best cytotoxic activity that has strong cell-growth inhibition with $\mathrm{IC}_{50} 56.19 \mu \mathrm{g} / \mathrm{ml}$.

\section{ACKNOWLEDGMENT}

As the authors of this work, we would love to express our ample thankfulness and gratitude to the Department of Chemistry, College of Science, University of Baghdad and College of Pharmacy, for their magnificent support and providing us with facilities to conduct this research on all accounts.

\section{REFERENCES}

1. Raut, A.B.; Matto, M. R.; Acta. Chim. Solv., 2008, 55,448.

2. Babak, K.; Leila, M.; Tetrahedron lett., 2011, 52,6424-6426.

3. Noha, I.Z.; Fabio, S .; Stefamo, F.; European. J. Med. Chem., 2010, 45, 4523.

4. Dali P.; Gautum, P.; Angpla, K.C.; European. J. Med. Chem., 2011, 46, 3085-3092.

5. Gopal, L.K.; Jasmine, K.; Varnm, K.; Bio. Organic. Med. Chem let., 2012, 22,1912-1916.

6. John, K.A.; Veeramani, V.P.; Sharmila, N. S.; Tetrahedron lett., 2009, 65, 9989-9996.

7. Aoyama, Y.; Uenaka, M.; Konoike, T.; Nakayima, M.; Bioorganic and Medicinal chemistry letters., 2001, 11, 1691.

8. James, A.H.; Glenn, S.T.; Robert, T.; Roger, M.E.; J. Antimicr. Chemoth., 2007, 4, 923.

9. Srivastava, S.K.; Srivastava, S.L.; Srivastava, S.D.; Indian J. Chem., 2000, 39, 464.

10. Vaishnav, P.; Demain, A.; Biotechnol. Adv., 2010, 7, 50.

11. Kolb, H.C.; Finn, M.G.; Sharpless, K.B.; Angew. Chem. Int. Ed., 2001, 40, 2004- 2021.

12. Kolb, H. C.; Sharpless, K. B.; Drug Discov. Today., 2003, 8, 1128-1137.

13. Moses, J. E.; Moorhouse, A. D.; Chem. Soc. Rev., 2007, 36, 1249-1262.

14. Tornøe, C.W.; Christensen, C.; J. Org. Chem., 2002, 67, 3057-3064.

15. Rostovtsev, V. V.; Green, L. G.; Fokin, V.V.; Sharpless, K.B.; Angew. Chem. Int. Ed., 2002, 41, 2596-2599.

16. Hiemstra, V. D.; Maarseveen, H. van; Eur. J. Org. Chem., 2006, 51-68.

17. Wu, P.; Fokin, V. V.; Aldrichim. Acta., 2007, 40, 7-17.

18. Meldal, M.; Tornøe, C.W.; Chem. Rev., 2008, 108, 2952-3015.
19. Wang, Q.; Chan, T. R.; Hilgraf, R.; Fokin, V.V.; Sharpless, K.B.; Finn M.G.; J. Am. Chem. Soc., 2003, 125, 3192

20. Manetsch, R.; Krasinski, A.; Radic, Z.; Raushel, J.; Tylor, P.; Sharpless, K.B.; Kolb H.C.; J. Am. Chem. Soc., 2004, 126,12809.

21. Helms, B.; Mynar, J. L.; Hawker, C. J.; Fréchet, J.M.; J. Am. Chem. Soc., 2004, 126, 15020.

22. Karim, A. M.; Park, J. S.; DSSCs. Macromol Chem Phys., 2008, 209, 1967.

23. Schirrmacher, R.; Wangler, C.; Schirrmacher, E.; Mini-Rev Org Chem., 2007, 4, 317.

24. Hussein, F.; Hello, K. M.; J. of Chem., 2002, 26(1), 35-41.

25. Abdulla, A. F.; MSc. Thesis, University of Baghdad, College of Science, 2015.

26. Hasan, A.;Thomas, N. F.; Gapil, S.; Molecules., 2011, 16(2), 1297-1309.

27. El-Tamaty, E. S.; Abdel-Fattah, M. E..; Indian J. Chem., 1996, 35, 1067.

28. Naser, A. W.; Iraqi National Journal of Chemistry., 2013, 50, 199.

29. Furniss, B.; Hannaford, A. H.; Smith, P.; Tatchell, A.; Vogel's Text book of practical organic chemistry, 5th Ed., Addison Wesley Longman, 1998, 1077.

30. Issac, Y. A.; Mohamed, S. K.; Eissa, A. M.; Tantawya, A. H.; EL-Sawya, A. A.; Journal of Chemical and Pharmaceutical Research., 2012, 4(5), 2744-2750.

31. Shneshil, M. K.; Ph.D. Thesis, University of Babylon, College of Science, 2016.

32. Denizot, F.; Lang, R.; J. of Immunological Methods., 1996, 89(2), 271-277.

33. Alshanon, A. F. ; Firas, H.; Abdul hameed, A. and Alsaffar, A. Z.; International Journal of Pharma Sciences., 2015, 5(1), 904-910. 